\title{
A Regional Social, Environmental and Economic Lifeline The Lake Gaston Water Supply Project
}

\author{
David She, P.E. Env. SP* \\ *David She is a Licensed Professional Engineer, Envision Sustainability Professional \\ Department of Public Utilities, City of Virginia Beach, VA USA
}

\begin{abstract}
Proactive water supply planning utilizes demand management strategies to promote the viability of future water supply. The Hampton Roads Region recognizes the importance of demand management and development efforts in water supply planning and also understands that it is crucial for the region to conserve local water resources and minimize both current and future water demands.

Based on the water resource studies, the Hampton Roads Region is pursuing programs and projects to meet long-term needs while providing interim and drought-related solutions. Incorporating water demand management practices both in the long and short term is a necessary component to extend the useful life of the regional water supply.

The Lake Gaston Water Supply Project is one of the most critical long-distance water supply pipeline projects in the region. It brings water from other watersheds and provides high quality, reliable fresh water to the Hampton Roads area. It has a positive and profound effect on the region's social, environmental, and economic impacts.
\end{abstract}

\section{INTRODUCTION}

South Hampton Roads in southern Virginia is a major population center located on the mid-Atlantic coast of the United States, with a total population of 1.7 million. The region is home to the largest military complex in the world.

This region has experienced rapid and steady population growth which has strained local water supplies. In addition, it is difficult to develop new water sources locally due to geological features. Water shortages in the region had become common place from the 70's thru 90's. Water restrictions or water quality impairments resulting from water shortages have occurred in every dry period during these three decades.

Numerous water resource studies and plans addressing regional water supply needs have been conducted. After many years of evaluation, the City of Virginia Beach decided to build a 76 miles $(122 \mathrm{~km})$ pipeline to extend an existing system of hydroelectric and flood control, the John Kerr Reservoir on the Roanoke River, which straddles the North Carolina and Virginia border and is operated by the United States Army Corps of Engineers.

The project transfers $60 \mathrm{MGD}\left(270,000 \mathrm{~m}^{3} / \mathrm{d}\right)$ of water from Lake Gaston to existing reservoirs in southeastern Virginia.

The City had completed the entirety of the study in addition to all of the engineering work, the property acquisition, the financing, and all other pre-construction activities before 1995. After receiving the last of the required federal approvals, Virginia Beach initiated construction of the project in late 1995. The City completed all construction by December 1997. The project has been put into service since January 1, 1998.

There are about 20,000 individual pipe sections in the entire pipeline. Both ductile iron (DIP) and pre-stressed concrete cylinder pipe (PCCP) are assembled using slip joints in which a rubber gasket or O-ring seals the annular space between the bell end and the spigot end of the pipe. Pipe segments with working pressures ranging from 250 psi to $150 \mathrm{psi}$ were used in the 74 miles $(119 \mathrm{~km})$ section from the pump station to the weir/aeration structure. The last 2 miles $(3 \mathrm{~km})$ gravity flow section of pipe from the weir/aeration structure to the terminus has a working pressure of 40 psi.

Today, this magnificent project has been contributing to the Hampton Roads sustainable social, environmental and economic development. It has proved vital to the people's health and well-being. Virginia Beach has been a famous resort city with the longest pleasure beach and one of the best vacation destinations; it attracts millions of tourists from around the world every year.

\section{SOCIAL IMPACTS}

Located on the Mid-Atlantic Coast in the path of both 
cyclonic storms that move northeastward from the Gulf of Mexico and moisture that moves inland from the Atlantic Ocean (Figure 1), the Hampton Roads Region relies on these weather systems to provide needed rainfall to the area. However, it occasionally suffers

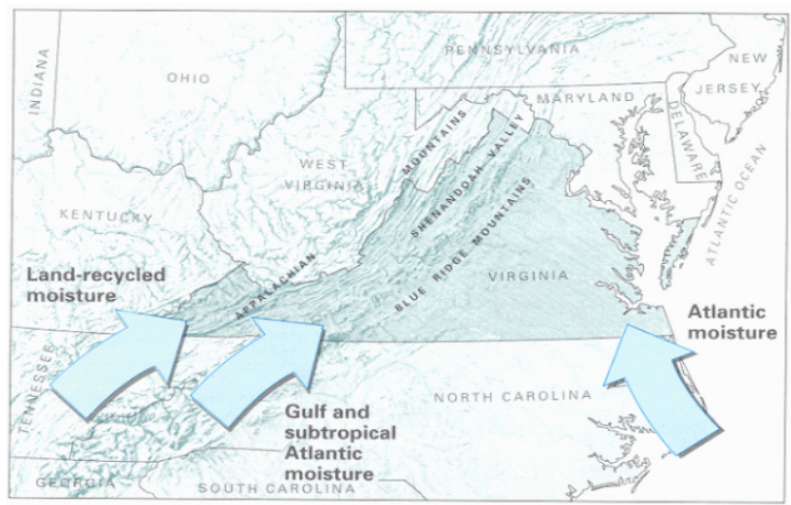

Figure 1. Hampton Roads Region Location Map severe flooding in its lower-lying coastal area.

Droughts, although generally less of a problem than floods, have also caused hundreds of millions of dollars to be lost and have resulted in severe water-supply shortages in the region. (See Table 1. and Figure 2.)

Table 1. Chronology of major and other floods and droughts in Virginia
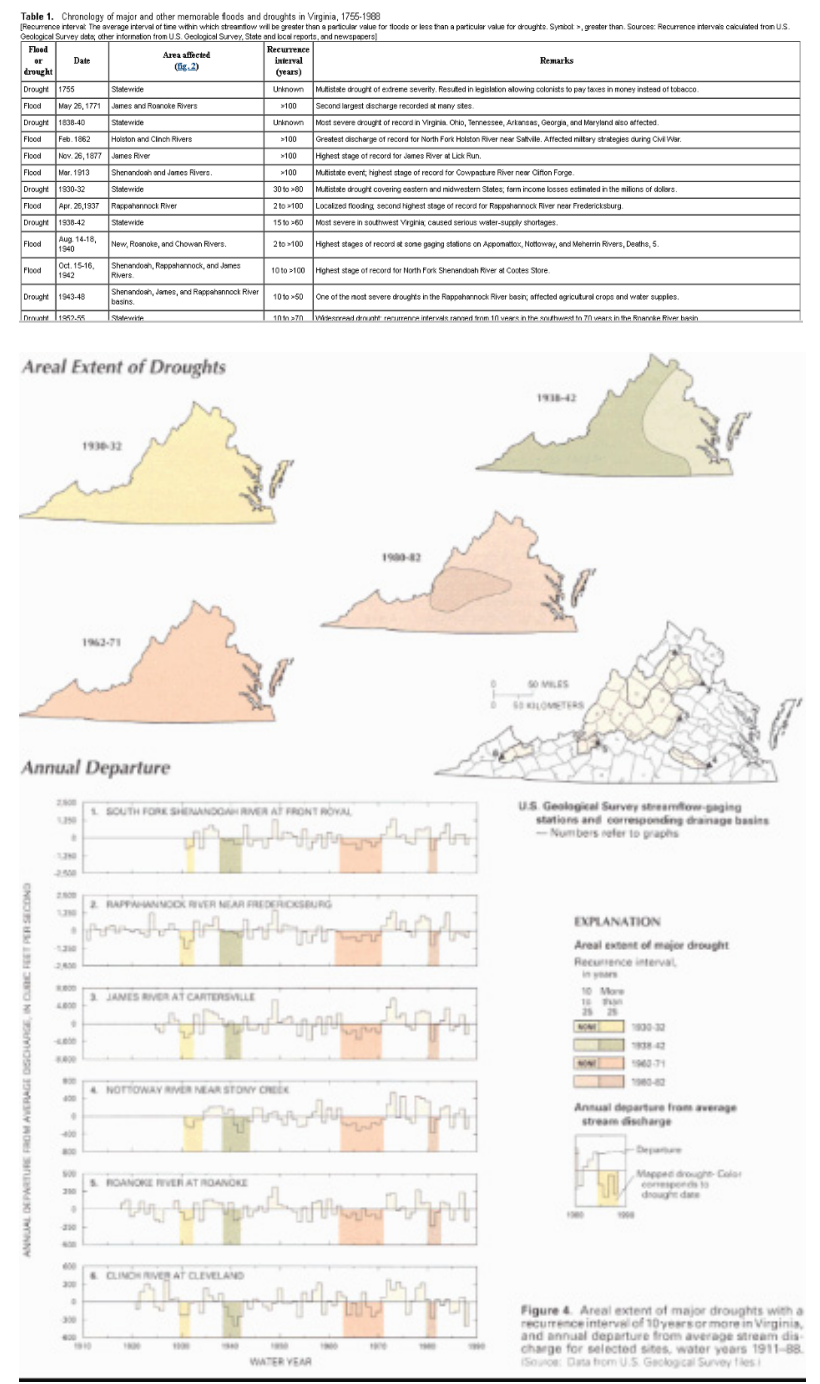

Figure 2. Areal Extent of Drought in Virginia
The region's water supply reservoirs have relatively small tributary watersheds and little natural water supply reserve. Most of the surface water in the region is salty and not readily available for drinking water and the groundwater resource is vulnerable to excessive use and saltwater intrusion.

Without a reliable water source, the region cannot continue its explosive growth. Virginia Beach, the city with the largest population in Virginia and one of the fastest growing in the nation, has considered everything from towing icebergs to the coastline to building a huge desalination plant to tap the Atlantic.

It's not unusual that the cities within the region fight with each other. Instead of constantly putting them in water war, in 1982, the City of Virginia Beach and several other cities and localities decided to pursue the Lake Gaston Water Supply Project. See Figure 3 for the project map.

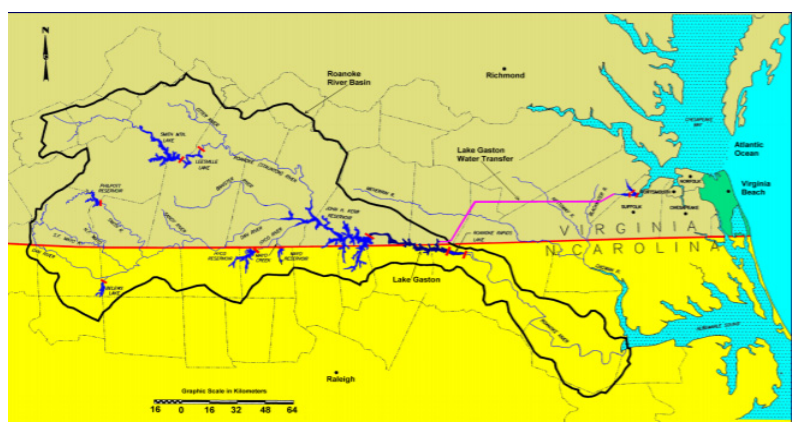

Figure 3. Lake Gaston Water Supply Project Map

But the ambitious pipeline plan, which was approved by the Army Corps of Engineers, irritated North Carolinians because its intake was planned to be located near the Virginia-North Carolina border, alarmed environmentalists and sparked one of the stormiest water wars on the East Coast. Followed by a 15 -year permitting and legal journey, the project finally started in late 90's.

According to most experts and other technical evaluations done after the pipeline in service for two decades, concerns about the pipeline's effects on wildlife and the localities through which it passes have proved unfounded.

\section{ENVIRONMENTAL IMPACT}

It's no doubt that sea level is rising at an accelerating rate - especially along the U.S. East Coast and Gulf Mexico.

The Hampton Roads Region is the second highest rise area in the U.S.A. Over 10 inches $(25.4 \mathrm{~cm})$ of sea level rise in the last 50 years has been observed in this area.

While Figure 4 shows 13 regions along the coastal areas, Figure 5 shows the trends for this specific region. It is predicted the rising speed is approximately $4.57 \mathrm{~mm} /$ year in the next 50 years. 


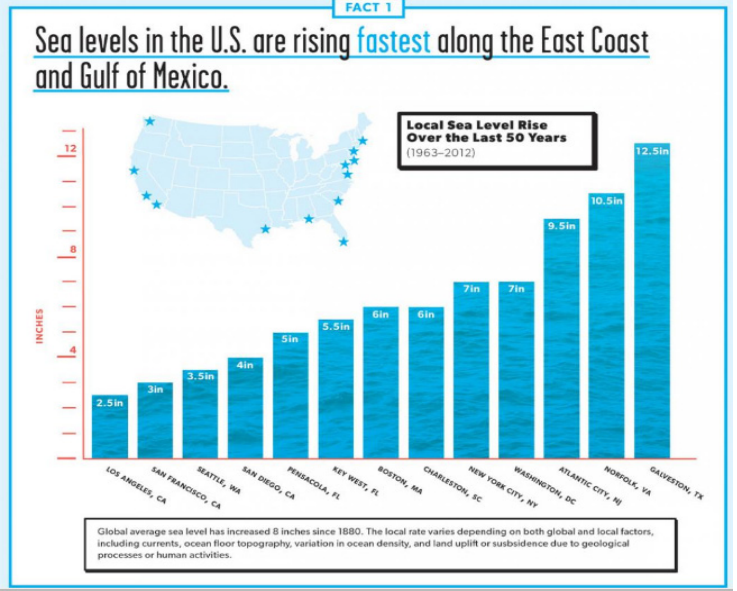

Figure 4. Sea Level Rise Historical Data

\section{Sea Level Rise in Hampton Roads}

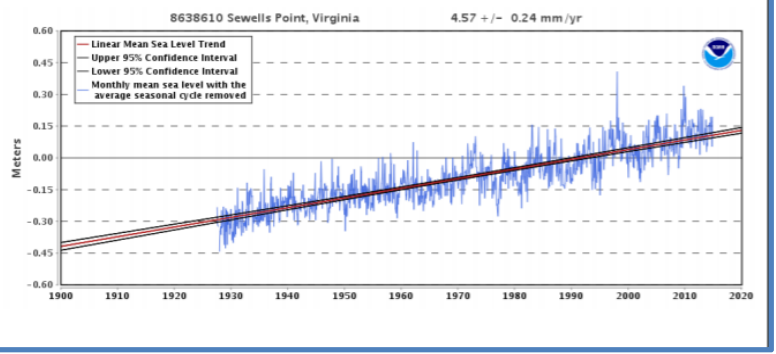

Figure 5. Sea Level Rise in Hampton Roads

Some research suggests that, along with melting ice sheets and glaciers, the water pumped from underground for public water usage could contribute substantially to rising sea levels, which can further lead to saltwater intrusion. This occurs when extraction of groundwater creates a depression of water levels surrounding the well, or a "cone of depression," that reverses the natural hydraulic gradient landward rather than seaward. Overexploitation of groundwater resources in coastal regions is known to intensify land subsidence, a phenomenon that accelerates the impacts of relative sea level rise.

To mitigate all of these negative effects, the Department of Environmental Quality has proposed major cuts to big groundwater users in the Hampton Roads Region. The Lake Gaston project has relieved much of the Region's dependency on municipal groundwater withdrawals. Because it reduced groundwater withdrawals from the regional aquifer, the project may be playing a significant role in reducing land subsidence. Moreover, at the downstream of the municipal water use, the Sustainable Water Initiative for Tomorrow (SWIFT) by the Hampton Roads Sanitation District (HRSD) has proposed to recharge the groundwater supply by treating wastewater to drinking water quality standards and injecting it into the aquifer.

\section{Which Direction Does the Ground Move?}

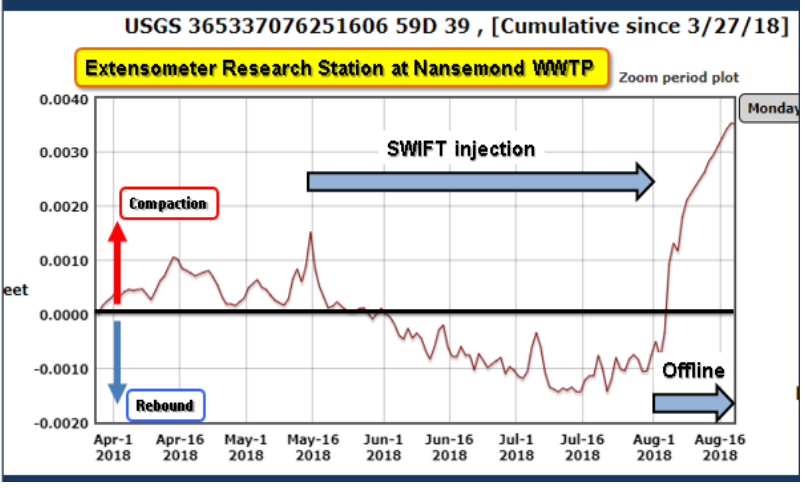

Figure 6. SWIFT and Land Movement

All of these efforts will slow down the sea level rise in the region. Figure 6 shows the most recent activity of SWIFT and the reaction of the land.

In addition, from the start to the end of the pipeline, the project was designed and constructed environmentally. The heart of the Lake Gaston project is the pump station and associated facilities located on the shores of Lake Gaston at Pea Hill Creek (See Picture 1).

The pump station is based upon a flooded wet well design. Underneath the pump station is a large, deep basement, the bottom of which is some $35 \mathrm{ft}(10.6 \mathrm{~m})$ below the normal pool level of the lake. Two 60 -inch $(1.5 \mathrm{~m})$ diameter pipelines connect the well to a series of intake screens, several hundred feet offshore. Verticalturbine centrifugal pumps, which extend down into the well, pump the water from the well into the pipeline.

The top of the intake screens are $15 \mathrm{ft}(4.6 \mathrm{~m})$ below the normal pool level of the lake. The screen size is $1 \mathrm{~mm}$. Maximum velocity at the screen surface is $0.5 \mathrm{ft} / \mathrm{s}$ $(0.15 \mathrm{~m} / \mathrm{s})$. One inch away from the screen surface, the velocity is reduced to $30 \%$. The withdrawal of water through the intake screens will not disturb the water surface.

The pump station facilities are located on a small peninsula on the lake. In order to lessen the environmental impact of the entire lake, the City made a serious commitment to design and construct a facility that would be both quiet and aesthetically pleasing. See Photo 1 for the pump station view.

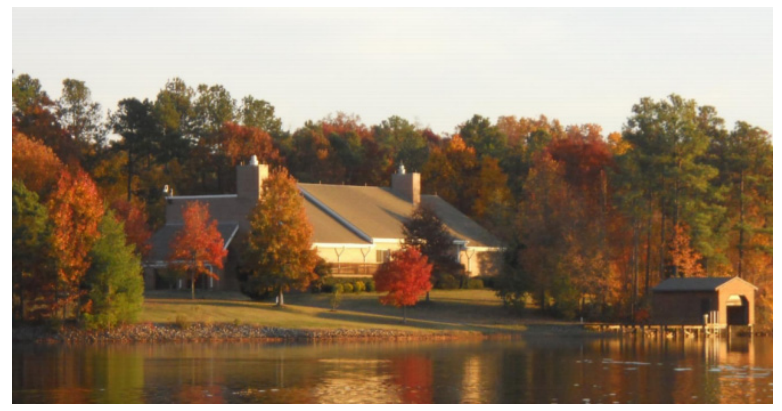

Picture 1. Pump Station located at the lakeshore

The flooded wet well design and the use of submerged vertical-turbine pumps keeps much of the noise contained in an underground vault of concrete surrounded by tons of rock and earth. The wet well design also keeps much of the pump station underground which allows for a relatively low visual profile from the Lake. 
The motors selected are among the quietest available for that size and type. Finally, the interior of the pump station is lined with a special sound reducing concrete block. Recent noise level tests have indicated that the City's efforts have been successful beyond its expectations. The pump station is so quiet, no one outside of the pump station is able to detect any noise.

The architects also made extensive efforts to ensure that the pump station and its associated facilities would be as attractive as they were quiet. Both the profile and the footprint of the pump station were kept as low as possible. The buildings were upgraded so that they would:

- look very attractive,

- require very little maintenance,

- last a very long time, and

- $\quad$ survive major storms with little or no damage.

Leaving the pump station site, the 60 -in $(152 \mathrm{~cm})$ diameter pipeline is approximately 76 miles $(122 \mathrm{~km})$ long. Except for the six river aerial crossings, the pipeline was installed approximately 6-7ft $(2 \mathrm{~m})$ deep below the surface. It runs in line with the power line and railroad right-ofway, because the areas were already cleared, the total acreage of trees that had to be cut and permanently removed was very little. The overall construction areas were restricted with little or no impact to the wetlands or the environment. See Picture 2 for an overview of the pipeline during construction.

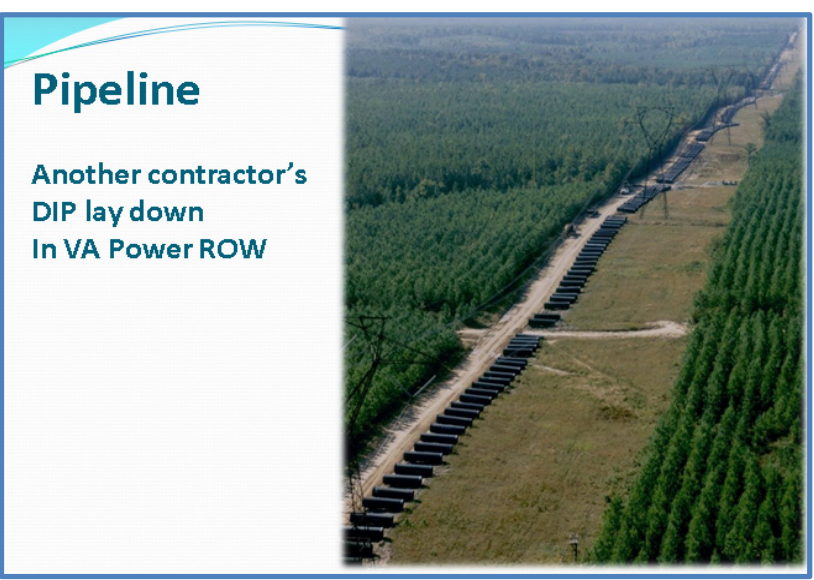

Picture 2. Pipes are ready for installation

Even at the outfall, the pipeline is hard to recognize. It is a concrete structure off a rural road. The fresh water from the pipeline flows into a natural channel that merges with other channels, eventually delivering the water into a larger reservoir.

\section{ECONOMIC IMPACT}

Prior to implementing this water supply project, several studies were conducted to analyze the financial benefits of the project.

All alternatives were sized to provide at least the projected treated water demands of the average 44 MGD and maximum 66 MGD. Virginia Beach's share of the Lake Gaston project is at $50 \mathrm{MGD}$ as raw water.

On the other hand, two seawater desalting alternatives were evaluated and compared. The first assumed that Virginia Beach and Norfolk would be able to reach an agreement on a long-term Sales Contract to purchase surplus water for/from Norfolk, and that the balance of its needs would be met by seawater desalting. The seawater desalting facilities were sized based upon the "Dry Year." This would require a seawater desalting facility, including related appurtenances and infrastructure of $36 \mathrm{MGD}$. The second seawater desalting alternative assumed that all of Virginia Beach's water needs would be met by seawater desalting. The plant and its appurtenant facilities were sized at 66 MGD capacity.

A cost comparison of multiple alternatives is listed in Table 2. It is obvious that in unit cost, the seawater desalting method is the most expensive and the water from Lake Gaston is the least.

Table 2. Cost Comparison of Alternatives

\begin{tabular}{|c|c|c|c|}
\hline \multicolumn{4}{|c|}{$\begin{array}{l}\text { Cost Comparison of Alternatives } \\
\text { (Costs in millions of dollars per year, unless otherwise noted) }\end{array}$} \\
\hline & Lake Gaston & \begin{tabular}{c|}
$\begin{array}{c}\text { Norfolk/SeawaterD } \\
\text { esalting }\end{array}$ \\
\end{tabular} & Seawater Desalting \\
\hline $\begin{array}{l}\text { Average Water } \\
\text { Demand (1996-2010) }\end{array}$ & $39.6 \mathrm{mgd}$ & $39.6 \mathrm{mgd}$ & $39.6 \mathrm{mgd}$ \\
\hline $\begin{array}{l}\text { Average Gaston } \\
\text { Supply }\end{array}$ & $39.6 \mathrm{mgd}$ & & \\
\hline $\begin{array}{l}\text { Average Norfolk } \\
\text { Surplus }\end{array}$ & & $25.0 \mathrm{mgd}$ & \\
\hline $\begin{array}{l}\text { Average Desalted } \\
\text { Supply }\end{array}$ & & $14.6 \mathrm{mgd}$ & $39.6 \mathrm{mgd}$ \\
\hline $\begin{array}{l}\text { Norfolk Fixed } \\
\text { CapacityCharge }\end{array}$ & 16 & 10.667 & \\
\hline $\begin{array}{l}\text { Norfolk Fixed } \\
\text { O\&M(0.35/kgal) }\end{array}$ & 7.592 & 4.791 & \\
\hline $\begin{array}{l}\text { Norfolk Variable } \\
\text { O\&M }(0.26 / \mathrm{kgal})\end{array}$ & 3.76 & 2.373 & \\
\hline $\begin{array}{l}\text { Norfolk Water } \\
\text { Charge( }(0.60 / \mathrm{kgal})\end{array}$ & & 5.475 & \\
\hline $\begin{array}{l}\text { Lake Gaston Debt } \\
\text { Service }\end{array}$ & 11.345 & & \\
\hline $\begin{array}{l}\text { Lake Gaston } \\
\text { O\&M(0.10/kgal) }\end{array}$ & 1.446 & & \\
\hline $\begin{array}{l}\text { Desalting Plant } \\
\text { DebtSenice }\end{array}$ & & 26.138 & 35.94 \\
\hline $\begin{array}{l}\text { Desalting Fixed } \\
\text { O\&M }(0.77 / \mathrm{kgal})\end{array}$ & & 6.163 & 16.703 \\
\hline $\begin{array}{l}\text { Desalting Variable } \\
\text { O\&M(2.04/kgal) }\end{array}$ & & 10.886 & 29.501 \\
\hline $\begin{array}{l}\text { Total Annual Cost } \\
\text { (millions of dollars/yr) }\end{array}$ & 40.143 & 66.492 & 82.143 \\
\hline $\begin{array}{l}\text { Total Unit Cost } \\
\text { (\$/kgal) }\end{array}$ & 2.79 & 4.61 & 5.69 \\
\hline
\end{tabular}

Ever since the project was put into formal service in 1998, the local economy has shown steady growth: Figure 7 shows the region's employment rate which has experienced a steady climb after the year 2000. It is no doubt that the Regional Water Supply Project has contributed to the local economic development and population growth. The reliable water source and high quality of product brings important benefits not only to the local government confidence level, but also to the society as a whole, and it remains a robust engine for economy.

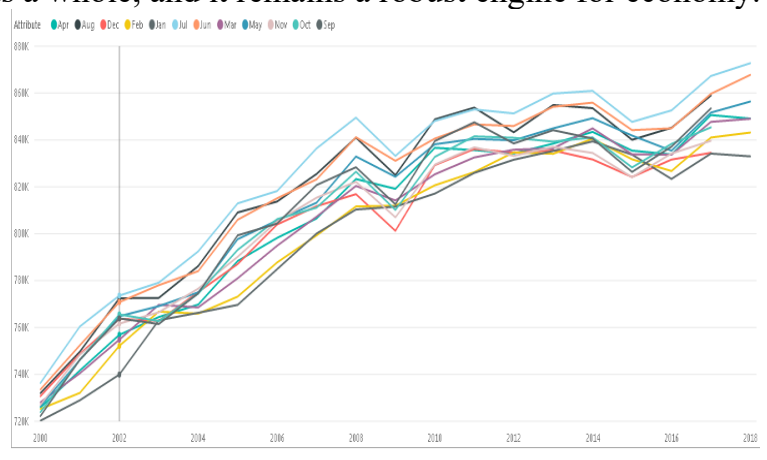

Figure 7. Employment Rate Statistic for Hampton Roads 


\section{CONCLUSION}

Water is at the core of sustainable development and is critical for socio-economic development, healthy ecosystems, and for human survival itself. Water shortages due to its uneven distribution in time and space can be resolved by man-made projects. A successful water supply pipeline to a city or a region is like a healthy blood vessel to a body.

It may be a challenge to start a water supply project for some areas in the world. Perhaps the most important step in a project like this one is to get it started. The government agencies should take leads to handle the work and seek every possible solution to accomplish it. Because every single water supply project is for the welfare of people, it has proven to have profound impacts to many aspects of the social, environmental, and economic development.

\section{REFERENCES}

1. Hampton Roads Water Supply Plan, July 2011

2. Sea Level Rise in Hampton Roads Final Report, March 2011

3. Kurt Stephenson, Economic Impacts of Coastal Plain Aquifer Depletion and Actions for Long-Term Availability and Productivity, August 2014

4. U.S. Geological Survey Water-Supply Paper 2375. 1988-89--Floods and Droughts

5. City of Virginia Beach Department of Public Utilities. Comprehensive Water Master Plan (2015 CWMP). April 2017. 